\title{
Ensuring Openness without Reinventing the Wheel
}

\section{Die Grundkonzepte des organisationalen Lernens scheinen einfach: Lernen, Dinge besser oder anders zu machen, und schädliches Wissen zu verlernen. Doch in der Praxis gibt es in Unternehmen eine Vielzahl von Blockaden für Lernprozesse. Erfolgreiche Lernprozesse zu gewährleisten, stellt nicht nur Führungskräfte vor erhebliche Herausforderungen. Und gerade das wiedererwachte Interesse an der Sozial- und Umweltberichterstattung zeigt, dass die daverhafte Sicherung von Lernerfolgen schwierig ist.}

I Von Ariane Berthoin Antal s organizational learning just another management fad whose time has already passed? Don't organizations have enough on their plates without adding learning to the agenda? The answer to both questions is a resounding ,no!" if we want to have a sustainable socioeconomic system in a sustainable natural environment. Too many current activities and processes in companies have significant negative impacts and must be changed. Such changes require learning at various organizational levels. Organizational learning is not simply an "add-on" to the agenda; it is a core competence to achieve goals. So, what are the key concepts and how can they be applied effectively to improve the environmental performance of companies?

\section{Key Concepts Seem Easy...}

Organizational learning is about figuring out how we can do things better, how to do different (and hopefully better) things, and how to stop doing things that may once have been positive and appropriate but are now detrimental. The literature refers to these skills as single-loop and doubleloop learning, and unlearning (1). Organizations must become skilled at all three types of learning and they have to distinguish between situations that require the one or the other type. It may sound exciting to engage in double-loop learning but if all that is needed is an improvement on existing processes, anything else is a waste of time and energy. It is equally dangerous to limit learning to tinkering with small adjustments to routines when the radical nature of changes in the situation requires the decision to do something significantly different from the past. Lastly, the concept of unlearning is a valuable reminder that learning is not a purely cumulative process. In order to be able to learn how to do something differently, it is often necessary to stop doing something one has done well.

Organizational learning is essentially a creative and interactive process. It is sometimes achieved by acquiring and applying existing knowledge and sometimes by generating new knowledge. In both situations, creativity is required because the transfer of knowledge from one context to another is never a simple copying process. The approach generated in one context must be adapted to the different context in order to be effective there. People must communicate with one another about what made an idea or a technique work well in one setting and then explore what needs to be put in place so that the idea works in the other setting. No matter how many manuals or expert reports are written, interaction between people is needed to draw out the tacit knowledge behind the formally codified knowledge. The "soft" knowledge that comes of experience and that is embedded in an organization's culture is often difficult to express but is an essential ingredient for ensuring that ideas work in practice.

\section{So why is it Difficult for Organizations to Learn?}

There are multiple blockages to organizational learning. For example, organizations tend to know far less than the sum of the knowledge of their members. This is because structures often block the flow of knowledge from one part of the organization to another and because the culture of the organization devalues the knowledge held outside the core power structure, such as in the lower echelons like call centers, or on the periphery like subsidiaries and sales forces. It is generally at the interfaces between the organization and its environment that new knowledge enters the organization, and at the periphery that experiments with new ways of doing things occur. If the available knowledge is not shared with others, old ways of seeing and doing things will persist even if they are no longer appropriate. Emerging problems remain unseen too long and emerging ways of dealing with them remain invisible when the flow of knowledge within organizations and between organizations and their sociopolitical environments is blocked.

Organizations with a long history of success are particularly prone to such blockages: they have established ways of doing things and prescribed information channels into and within the organization. Not until a crisis hits is there an incentive to question the appropriateness of traditional approaches. But a crisis is rarely a propitious moment for learning. During crises, companies tend to have competing factions fighting each other in interpreting the causes of the problem and defining the best way to deal with it. Some groups want to maintain old approaches while others argue for new ones. They usually end up paralyzing the organization. The equally dangerous alternative response to a crisis is hyperactivity. A multitude of new ideas are tried, with too little time to see how they work and to analyze the effects. The typical result is great confusion and little learning.

An additional and increasingly common barrier to organizational learning is information overload. The speed and ease with which information can now be collected and disseminated make it difficult to discern relevant signals. The internet and communications media, such as e-mail, have compounded the problem of information overload in the past few years. It is now possible to "know" nothing with a great deal of information at hand. Knowledge is more than information, it is information that has been given meaning. It is the outcome of an interpretation process that takes place within a framework of values and experience. For an organization to learn, agreement must be reached on what the available information means and what should be done about it. Conflicts arise because interpretations are likely to vary. The process of working through these conflicts can be very useful for learning. If conflicts are avoided or unresolved, it is difficult for the organization to learn. 


\section{Who is Responsible?}

Organizations as such cannot learn - it is individuals who interact to acquire and generate knowledge and they embed it into the organization. They store it in the processes, structures, and culture so that it is available in the organization's memory even after those originally involved in the learning process are no longer around. The focus of research was originally on top management as bearing the primary responsibility for organizational learning, often with the support of strategic planners or similar experts. There is a current wave of interest in the creation of a new type of special role, the chief knowledge or learning officer, but the general agreement in the literature is that the responsibility for learning should be spread throughout the organization. Top management's role is to enable organizational learning rather than to manage or control it directly.

There are two primary challenges for managers seeking to stimulate organizational learning. The first is to have both the courage and the humility required to be seen as learners themselves. The pressure is high for leaders to demonstrate knowing rather than learning, because learning involves making mistakes and being uncertain at times. Learning leaders are crucial for mastering the second challenge: to create a culture that supports the flow of knowledge and the questio-

\section{Homo Sustainomicus? Öko-Wirtschaftsakteure zwischen Psychologie und neuer Mikroökonomik}

und voraussichtlich

\section{EU-Osterweiterung und Nachbaltigkeit}

sind die Themen der Informationsdienste

\section{Ökologisches Wirtschaften $6 / 02$ und $1 / 03$}

Wenn Sie potenzielle Beiträge haben, wenden Sie sich bitte an die Redaktion. ning of traditional ways of seeing and doing things. This implies recognizing and actively seeking out the knowledge that is held by people in different parts of the organization and stimulating others to obtain and value that knowledge independently of hierarchy or status. It also implies reviewing the impacts of organizational structures to see whether they are supporting the flow of knowledge to where it needs to go instead of serving as barriers to knowledge sharing. The formal and the informal rewards in the organization must also be in tune with knowledge sharing and learning processes. For example, if people are penalized for making mistakes, they are likely to try to avoid the risk or hide the error rather than using the experience as an opportunity for the organization to learn from. Similarly, if incentive systems are primarily individualistic or focused on one unit at the expense of another, it is unlikely that people will want to share their knowledge with others.

\section{New Challenges}

A culture that is open to learning will tend to have a high tolerance for non-conformists (2). This finding flies in the face of conventional wisdom about the importance of socializing employees quickly to share the organization's cultural norms and values. In order for an organization to acquire new knowledge and to generate fresh ideas, it must create space for people to think differently from one another and to feel safe in challenging the status quo. Managers must be skilled at finding a balance between articulating (not imposing) a generally shared sense of purpose and direction while remaining open to questioning and experimentation with different approaches.

There is growing recognition that learning is not done only by the members within the boundaries of one organization. The learning that happens between organizations is equally vital. Two trends are making this type of learning urgent. First, the boundaries between organizations and their customers and suppliers are becoming increasingly permeable. Second, the legitimacy of organizations depends largely on the way their performance is assessed by their stakeholders. After the recent meltdown of stock markets and the ethical debacles in accounting, the time has come for companies to remember that shareholders are only one of many stakeholders, and shareholder value is only one, very imperfect, measure of performance.
The ability of companies to learn from each other, from their suppliers and customers, from environmental groups and grass roots movements of all kinds is becoming a core competence that has to be mastered. This entails engaging with different mindsets and value systems in which different types of knowledge are considered relevant. Equally important, these diverse stakeholders must also learn how to engage in interorganizational learning processes if they really want to have an impact on business decisions and performance. Interorganizational learning requires that the various partners open themselves to the process together - it cannot be a one-sided process of persuasion or manipulation.

\section{Rediscovering a Learning Tool for the Environment}

The memory of organizations, including the memory of the academic and the policy-making communities is often astoundingly short. We are witnessing the rebirth of interest in corporate social accounting and reporting under various labels, including the triple bottom line and sustainability reporting (3). Few new publications (4) mention the experiments conducted in this area two decades ago, although European academics and companies, particularly in Germany and Switzerland, were considered leaders by the U.S. Department of Commerce at the time. We risk doing little more than reinventing the wheel. Even more dangerous, we risk not learning how to ensure that the issue stays on the attention cycle this time rather than being forgotten once again.

Companies tried a variety of approaches to corporate social reporting in the 1970 s and 1980s. They used quantitative and qualitative indicators to document the impact of their activities on the sociopolitical and natural environment. The most advanced form at the time was goal accounting and reporting, which assessed the companies' performance based on their commitments to society. The Swiss-based corporation Migros Genossenschaftsbund, for example, drew on its overall mission and vision statement to formulate goals in different policy areas and it asked its diverse stakeholders to rate the commitments to ensure that they were seen as relevant. It then reported extensively on its performance in biennial reports in several languages and in a format that permitted comparisons over time.

Although many companies learned from their experiments, it was clear by the mid-1980s that most of the corporate community was unlikely to 
follow the pioneer companies voluntarily. The political environment changed in many countries. The climate was not propitious for regulation, except in France, but the French social report was - and still is - narrowly focused on employee affairs. So the interest in corporate social reporting waned in the $1980 \mathrm{~s}$ and all but disappeared in the 1990s under the pressures for shareholder value.

\section{- Promising Trends}

Today, two developments offer new opportunities for learning how to improve business's ability to perform in a manner that promotes socioeconomic and environmental sustainability. Companies and their stakeholders can use these developments to figure out how to do certain things better, do better things, and how to stop doing detrimental things. First is the convergence between the attention being paid to the social, economic, and environmental aspects of business social performance. This trend offers the opportunity to ensure that the topic stays on the agenda by creating a broad, powerful platform. To make sense of the often apparently conflicting and unrealistic expectations for performing well in all three areas, managers must become skilled at interacting with multiple stakeholders. Only then will they understand and, equally important, actively manage stakeholder expectations well enough to formulate achievable targets.

The second trend that offers an opportunity is the expansion of the internet. The internet should be used not only as a tool for the rapid transmission of data but also as an interactive medium for interorganizational learning. Companies are no longer the sole providers of information about their performance. If they are to have any credibility they must provide information that is considered relevant as well as correct by their stakeholders. This can only happen if the companies and stakeholders agree on the nature of the knowledge they need in order to assess corporate performance. Interesting initiatives for standardizing corporate social and environmental reports have been put forward recently to enable comparability between organizations and over time (such as the Global Reporting Initiative; the Green Paper on Corporate Social Responsibility of the European Commission, and the Social Accountability 8000 initiative (3).

Total standardization, however, does not reflect the importance of context, so such reports may well contribute more to information overload than to actually usable knowledge. Knowledge by its very nature is generated in context and its relevance is linked to context. Therefore, companies and their stakeholders will need to explore once again the concept of goal accounting and reporting because it provides the contextual framework for generating and assessing information about a company's performance. The key will lie in approaching the task as an interactive learning process from the outset. Leading-edge companies will use the internet as a medium for engaging with a diverse range of stakeholders in an ongoing manner rather than limiting themselves to publishing a standardized report at the end of an accounting period. By using new communications media and such tools as interactive goal accounting and reporting, companies and their stakeholders will find ways of improving existing processes for achieving socioeconomic and ecological sustainability, discover new ones, and identify those activities they must unlearn.

\section{Notes}

(1) For a thorough review see Dierkes, M./ Berthoin Antal, A./ Child, J./ Nonaka, I. (eds.): Handbook of Organizational Learning and Knowledge. Oxford University Press, $0 x$ ford 2001.

(2) See Berthoin Antal, A./ Krebsbach-Gnath, C. (Hrsg.): Wo wären wir ohne die Verrückten? Zur Rolle von Außenseitern in Wissenschaft, Politik und Wirtschaft. edition sigma, Berlin 2001.

(3) See Ökologisches Wirtschaften 1/2001 and Berthoin Antal, A./ Dierkes, M./ MacMillan, K./ Marz, L.: Corporate Social Reporting Revisited, WZB discussion paper FS II 02 105, Berlin 2002.

(4) An exception is Institut für ökologische Wirtschaftsforschung/ Institut für Markt-Umwelt-Gesellschaft (Hrsg.): Nachhaltigkeitsberichterstattung. Erich Schmidt Verlag, Berlin 2001, S. 69-79.

\section{Die Autorin}

Prof. Dr. Ariane Berthoin Antal leitet das Forschungsprogramm zu Organisationslernen am Wissenschaftszentrum Berlin für Sozialforschung (WZB) und ist Honorarprofessorin an der Technischen Universität Berlin. Kontakt: WZB, Reichpietschufer 50, 10785 Berlin, Tel. 030/ 25491-625; Fax -213;

E-Mail: ABAntal@wz-berlin.de

\section{Neu im ökom Verlag}

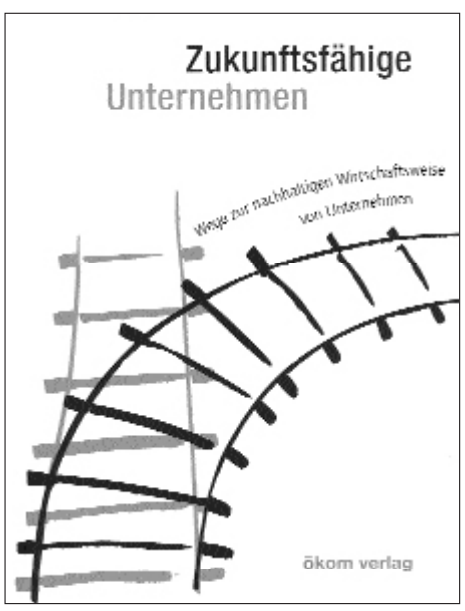

\section{Zukunftsfähige \\ Unternehmen}

Die Weichen für zukunftsfähiges Wirtschaften sind gestellt. Einige Firmen sind schon auf diesen Zug aufgesprungen und gehen offensiv mit ihrer sozialen und ökologischen Verantwortung um. Wer sind diese modernen Unternehmen und auf welche Konzepte stützen sie sich? Das Buch gibt Pionieren aus Wirtschaft, Wissenschaft und Gesellschaft alles Wissenswerte für eine nachhaltige Wirtschaftsweise an die Hand.

Theorie_AutorInnen aus Wissenschaft, Unternehmen und Verbänden entwerfen in ihren fundierten Beiträgen Konzepte einer nachhaltigen Unternehmensführung.

Praxis_23 Unternehmen unterschiedlicher Branchen berichten über ihre Erfahrungen und best practice Beispiele. Sie zeigen, dass es keine Standardlösungen gibt, sondern jedes Unternehmen zur eigenen Strategie und Kultur der Nachhaltigkeit finden muss. Vision_Die Herausgeber und Unternehmer starten mit diesem Buch einen offenen Diskurs. Der Weg für Kooperationen, Diskussionsrunden und weitere Projekte zwischen Umweltverbänden und Unternehmen ist damit bereitet.

BUND und UnternehmensGrün (Hrsg.)

ökom Verlag München, 2002

256 Seiten, Preis 18,50 Euro, ISBN 3-928244-81-7

\section{www.oekom.de}

erhältlich bei pan adress

Semmelweisstraße 8, D-82152 Planegg

Fon $++49 /(0) 89 / 857$ 09-155

Fax $++49 /(0) 89 / 857$ 09-131

E-Mail kontakt@oekom.de 
(c) 20I0 Authors; licensee IÖW and oekom verlag. This is an article distributed under the terms of the Creative Commons Attribution Non-Commercial No Derivates License (http://creativecommons.org/licenses/by-nc-nd/3.o/), which permits unrestricted use, distribution, and reproduction in any medium, provided the original work is properly cited. 